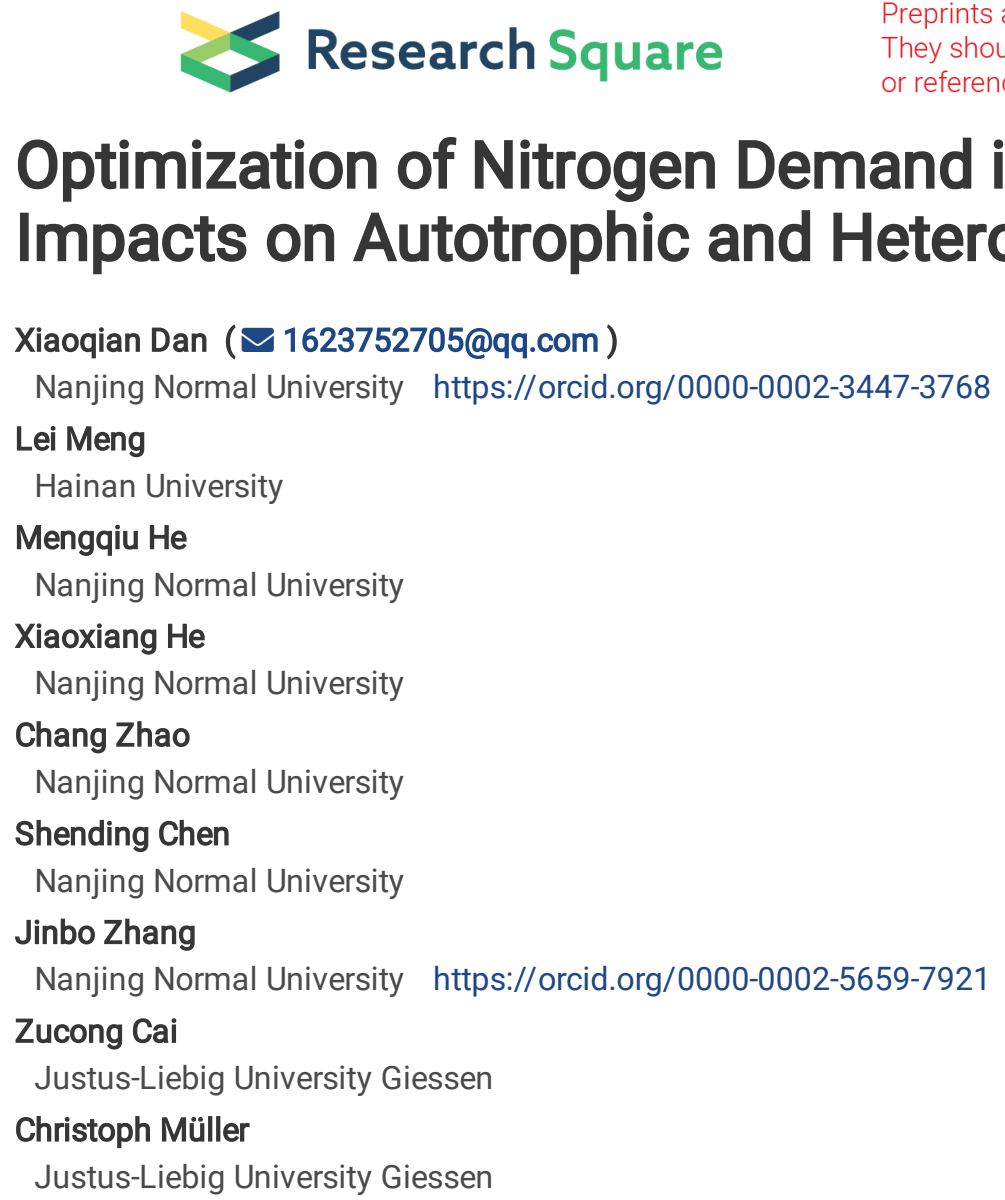

\title{
Optimization of Nitrogen Demand in Vegetables by Different Impacts on Autotrophic and Heterotrophic Nitrification
}

Research Article

Keywords: Nitrogen acquisition, Ntraceplant tool, Gross N transformation rates, Greenhouse soil

Posted Date: January 3rd, 2022

DOI: https://doi.org/10.21203/rs.3.rs-1147105/v1

License: () (1) This work is licensed under a Creative Commons Attribution 4.0 International License. Read Full License 


\section{Abstract}

Aims The understanding of the interactions between $\mathrm{N}$ transformations and $\mathrm{N}$ uptake by plants in greenhouse soils with large $\mathrm{N}$ accumulation is still not clear. The aim is to understand the plant- soil interactions (vegetables) on $\mathrm{N}$ transformations with respect to $\mathrm{N}$ supply.

Methods ${ }^{15} \mathrm{~N}$ tracing studies were conducted in two greenhouse soils to simultaneously quantify soil gross $\mathrm{N}$ transformation and plant $\mathrm{N}$ uptake rates using the $\mathrm{Ntrace}_{\text {plant }}$ tool. Results There were significant feedbacks between vegetable $\mathrm{N}$ uptake and soil gross $\mathrm{N}$ transformation rates, whether soil $\mathrm{N}$ accumulation occurred or not. Plant $\mathrm{NO}_{3}{ }^{-}$uptake rates $\left(U_{\mathrm{NO}}\right)$ were higher than the $\mathrm{NH}_{4}{ }^{+}$uptake rates $\left(U_{N H 4}\right)$, which is consistent with the $\mathrm{NO}_{3}{ }^{-}$-preference of the vegetable plants studied. While $U_{N H 4}$ was still responsible for $6-49 \%$ of total $\mathrm{N}$ uptake rates, significantly negative relationships between $\mathrm{U}_{\mathrm{NH} 4}$ and $\mathrm{NH}_{4}{ }^{+}$immobilization rate and autotrophic nitrification rate $\left(O_{N H 4}\right)$ were observed. $O_{N H 4}$ was significantly inhibited in the presence of plants and decreased with time. $O_{N H 4}\left(1.11 \mathrm{mg} \mathrm{N} \mathrm{kg}^{-1} \mathrm{~d}^{-1}\right)$ was much lower than $U_{\mathrm{NO} 3}\left(8.29 \mathrm{mg} \mathrm{N} \mathrm{kg}^{-1} \mathrm{~d}^{-1}\right)$ in the presence of plants. However, heterotrophic nitrification rate $\left(O_{\mathrm{Nrec}}\right)$, which ranged from 0.10 to $8.11 \mathrm{mg} \mathrm{N} \mathrm{kg}^{-1} \mathrm{~d}^{-1}$ was significantly stimulated and was responsible for $5-97 \%$ of $\mathrm{NO}_{3}{ }^{-}$production in all plant treatments, providing additional $\mathrm{NO}_{3}{ }^{-}$to meet $\mathrm{N}$ requirements of plants and microorganisms.

Conclusions The management of organic $\mathrm{N}$ fertilizers should be improved to stimulate inorganic $\mathrm{N}$ production via heterotrophic nitrification in greenhouse cultivation.

\section{Introduction}

Greenhouse vegetable cultivation (GVC) is increasingly used to meet the demand for vegetables and improve farmers' income (Min et al. 2016; Min et al. 2021). The area of GVC in China has reached approximately 4.67 million ha by 2018 , accounting for $83 \%$ of the global GVC (Cuesta 2019; Fei et al. 2018). Application of excessive nitrogen ( $N$ ) fertilizer to ensure high yields in GVC is common and is often 25 times higher than in open-air vegetable cultivation (OVC), sometimes exceeding $2000 \mathrm{~kg} \mathrm{~N} \mathrm{ha}^{-1} \mathrm{yr}^{-1}$ (Albornoz 2016; Congreves and Van Eerd 2015; Wang et al. 2018). The N use efficiency (NUE) of GVC ( $<20 \%)$ is generally much lower than in OVC (26\%-63\%) (Ren et al. 2010; $\mathrm{Ti}$ et al. 2015). Large amounts of $\mathrm{N}$ are accumulated in soils under GVC, leading to environmental pollution (e.g., groundwater contamination and $\mathrm{N}_{2} \mathrm{O}$ emission) and soil degradation (Guo et al. 2010; Li et al. 2018; Zhou et al. 2016). Large $\mathrm{N}$ application rates can also affect soil $\mathrm{N}$ transformations (Zhu et al. 2011). Previous studies showed that the rate of $\mathrm{NH}_{4}{ }^{+}$oxidation to $\mathrm{NO}_{3}{ }^{-}$(i.e. autotrophic nitrification rate) in greenhouse soils was stimulated by substantial amounts of $\mathrm{N}$ fertilizer supply, while microbial $\mathrm{N}$ immobilization rates decreased due to the reduction of SOC and C/N ratio in long-term GVC, resulting in an accumulation of $\mathrm{NO}_{3}{ }^{-}$(Sun et al. 2020; Zhu et al. 2011). The interaction of soil gross $\mathrm{N}$ transformations can regulate forms, contents and fates of $\mathrm{N}$, which is affecting plant $\mathrm{N}$ uptake (Zhang et al. 2018). Moreover, plant $\mathrm{N}$ acquisition can alter soil physical, chemical, and biological properties, and in turn affect gross $\mathrm{N}$ transformation rates (He et al. 2021; Nacry et al. 2013; Waring et al. 2015). To enhancing vegetable N uptake, it is important to understand the feedbacks between soil $\mathrm{N}$ transformations and plant $\mathrm{N}$ uptake in soil-plant systems under GVC. However, to date, the understanding of interactions between gross $\mathrm{N}$ transformations and plant $\mathrm{N}$ uptake in GVC soils with large $\mathrm{N}$ accumulation is still not clear.

Previous studies have focused on the feedbacks between plant $\mathrm{N}$ uptake and soil gross $\mathrm{N}$ transformations in soils with low $\mathrm{N}$ content. For instance, $\mathrm{NH}_{4}{ }^{+}$-preference plants (such as sorghum and rice) can exudate nitrification inhibitors to inhibit Nitrosomonas (belonging to $\mathrm{AOB}$ ) and further suppress autotrophic nitrification to maintain soil $\mathrm{NH}_{4}{ }^{+}$concentrations and meet their $\mathrm{NH}_{4}{ }^{+}$requirements (Subbarao et al. 2013; Subbarao et al. 2015; Sun et al. 2016). Recently it was shown that $\mathrm{NH}_{4}{ }^{+}$-preference plants (i.e. sugarcane and tea) possessed a stronger $\mathrm{NH}_{4}{ }^{+}$-competition capacity than soil microorganisms, which led to a decrease in $\mathrm{NH}_{4}{ }^{+}$immobilization rate in acidic forest soil (He et al. 2021). Furthermore, $\mathrm{N}$ transformations in the soil, such as mineralization and heterotrophic nitrification, were stimulated by plants through the release of root exudates and the recruitment of beneficial microorganisms (such as bacteria and fungi) (He et al. 2020; He et al. 2021; Hill et al. 2012; Nacry et al. 2013). However, in soils with large N accumulation (e.g. GVC soil), little is known about the feedbacks between plant $\mathrm{N}$ uptake rates and soil gross $\mathrm{N}$ transformation rates.

We hypothesized that 1) Vegetables depend mainly on the amount of available $\mathrm{N}$ in the soil, which is reflected in weak feedbacks on the processes of mineral $\mathrm{N}$ production in the soil, e.g. $\mathrm{N}$ mineralization and heterotrophic nitrification; 2) Vegetables generally prefer $\mathrm{NO}_{3}{ }^{-}$, thus they should stimulate autotrophic nitrification to meet their $\mathrm{NO}_{3}{ }^{-}$demand. In this study, two main varieties of vegetables under $\mathrm{GVC}$ 
(i.e. tomato (Lycopersicon esculentum L.) and cucumber (Cucumis sativus L.)) and two greenhouse soils with different $\mathrm{N}$ accumulation were selected. To test our hypotheses, a series of ${ }^{15} \mathrm{~N}$-tracing studies were carried out to quantify soil gross $\mathrm{N}$ transformation rates and plant $\mathrm{N}$ uptake rates.

\section{Material And Methods}

Soil samples

Two greenhouse soil samples were collected from Suzhou, Jiangsu Province, China. On one soil, tomato and strawberry were grown continuously for more than 10 years, with a high accumulation of $\mathrm{NO}_{3}^{-}$(on average $82.83 \mathrm{mg} \mathrm{N} \mathrm{kg}^{-1}$ ) (HS). The other was previously planted with tomato and cucumber and lay fallow for several years, resulting in a low $\mathrm{NO}_{3}{ }^{-}$concentration (on average $8.97 \mathrm{mg} \mathrm{N} \mathrm{kg}^{-1}$ ) (LS). Four plots $(1 \mathrm{~m} \cdot 1 \mathrm{~m})$ were randomly selected at each sampling site. The surface soil $(0-20 \mathrm{~cm})$ was collected and pooled together in equal amounts. Then soil samples were immediately passed through a $2 \mathrm{~mm}$ sieve and roots were removed. Each sample was divided into three sub-samples. One was air-dried to determine soil chemical properties (Table 1), one was stored in a refrigerator at $-80^{\circ} \mathrm{C}$ for the measurement of soil microbial properties, and another sub-sample was stored at $4{ }^{\circ} \mathrm{C}$ to perform ${ }^{15} \mathrm{~N}$ tracing studies.

Table 1

soil properties of initial HS and LS (means $\pm S D, n=3$ )

\begin{tabular}{|c|c|c|c|c|c|c|c|c|}
\hline & $\mathrm{pH}$ & $\begin{array}{l}\mathrm{EC} \\
\mu \mathrm{S} \mathrm{cm}^{-1}\end{array}$ & $\mathrm{C} / \mathrm{N}$ & $\begin{array}{l}\text { SOC } \\
\mathrm{g} \mathrm{kg}^{-1}\end{array}$ & $\begin{array}{l}\mathrm{TN} \\
\mathrm{g} \mathrm{kg}^{-1}\end{array}$ & $\begin{array}{l}\text { DOC } \\
\mathrm{mg} \mathrm{kg}^{-1}\end{array}$ & $\begin{array}{l}\mathrm{NH}_{4}^{+} \\
\mathrm{mg} \mathrm{kg}^{-1}\end{array}$ & $\begin{array}{l}\mathrm{NO}_{3}^{-} \\
\mathrm{mg} \mathrm{kg}^{-1}\end{array}$ \\
\hline LS & $7.76 \pm 0.03 a$ & $55.42 \pm 1.39 b$ & $8.81 \pm 0.12 a$ & $6.73 \pm 0.07 b$ & $0.76 \pm 0.02 b$ & $143.50 \pm 8.49 a$ & $1.05 \pm 0.13 a$ & $8.97 \pm 0.06 b$ \\
\hline \multirow[t]{3}{*}{ HS } & $5.81 \pm 0.03 b$ & $430.43 \pm 5.76 a$ & $7.56 \pm 0.20 \mathrm{~b}$ & $12.19 \pm 0.12 a$ & $1.61 \pm 0.06 a$ & $154.70 \pm 7.23 a$ & $1.02 \pm 0.03 a$ & $82.83 \pm 1.01 a$ \\
\hline & TP & TK & AP & AK & Bacteria & Fungi & $\mathrm{AOA}$ & $\mathrm{AOB}$ \\
\hline & $\mathrm{g} \mathrm{kg}^{-1}$ & $\mathrm{~g} \mathrm{~kg}^{-1}$ & $\mathrm{mg} \mathrm{kg}^{-1}$ & $\mathrm{mg} \mathrm{kg}^{-1}$ & \multicolumn{4}{|c|}{$\log _{10}$ gene copies $\mathrm{g}^{-1}$ dry soil } \\
\hline LS & $0.52 \pm 0.04 b$ & $16.88 \pm 0.79 b$ & $18.97 \pm 1.15 b$ & $110.59 \pm 3.50 b$ & $9.97 \pm 0.02 a$ & $8.84 \pm 0.01 b$ & $7.79 \pm 0.02 b$ & $6.63 \pm 0.06 \mathrm{~b}$ \\
\hline HS & $1.40 \pm 0.06 a$ & $18.54 \pm 0.00 \mathrm{a}$ & $191.33 \pm 3.14 a$ & $260.08 \pm 3.50 a$ & $9.88 \pm 0.04 a$ & $9.03 \pm 0.01 a$ & $8.07 \pm 0.02 a$ & $6.96 \pm 0.04 a$ \\
\hline
\end{tabular}

The ${ }^{15} \mathrm{~N}$ tracing study

Two vegetables (tomato and cucumber) and two greenhouse soils (HS and LS) were selected for ${ }^{15} \mathrm{~N}$ tracing pot experiments. The experiment was carried out with four treatments, i.e. (1) HST, tomato planted in HS; (2) LST, tomato planted in LS; (3) HSC, cucumber planted in HS; (4) LSC, cucumber planted in LS. Three sub-treatments were set up for each treatment, i.e. without plant (CK), planting for 15 days (D15) and 26 days (D26). The seeds of tomato and cucumber were surface-sterilized with $5 \%$ alcohol and then rinsed with deionized water. The sterilized seeds were germinated on petri dishes placing in an incubator with $30^{\circ} \mathrm{C}$. The germinated seeds were transplanted to the seeding plug tray containing nutritional material (peat: vermiculite: perlite, 6:3:1). After tomato and cucumber seedlings had fully developed their first true leaf, the nutritional materials of seeding roots were removed and seedlings with uniform growth rate were selected and transplanted to pots with $200 \mathrm{~g}$ of soil each (oven-dry basis). In addition, a control treatment (without plants) was set up for each soil. Hoagland's nutrient solution was added to each pot. Topdressing (only $\mathrm{N}$ fertilizer) with a rate of $10 \mathrm{mg}$ $\mathrm{N} \mathrm{kg}^{-1}$ was applied every 6-days. All pots were cultured at daytime temperatures of $30-35^{\circ} \mathrm{C}$, night temperatures of $20-25^{\circ} \mathrm{C}$ and under artificial light intensity 5000 Lux ( $12 \mathrm{~h}$ light and $12 \mathrm{~h}$ dark cycle). Furthermore, water was added each day to maintain the soil water content at $60-70 \%$ water holding capacity and the air was humidified with a humidifier to create an environmental condition of the greenhouse, e.g. high temperature and humidity.

15 days (D15) and 26 days (D26) after transplanting the seedlings, respectively, ${ }^{15} \mathrm{~N}$ tracing pot experiments were conducted. Briefly, two ${ }^{15} \mathrm{~N}$ labeled treatments (three repetitions for each treatment), i.e. ${ }^{15} \mathrm{~N}$ labeled $\mathrm{NH}_{4}{ }^{+}\left({ }^{15} \mathrm{NH}_{4} \mathrm{NO}_{3}, 10.20\right.$ atom\%) and ${ }^{15} \mathrm{~N}^{2}$ labeled $\mathrm{NO}_{3}{ }^{-}$ 
$\left(\mathrm{NH}_{4}{ }^{15} \mathrm{NO}_{3}, 10.12\right.$ atom\%) were set up. $\mathrm{A} 2 \mathrm{~mL}{ }^{15} \mathrm{NH}_{4} \mathrm{NO}_{3}$ or $\mathrm{NH}_{4}{ }^{15} \mathrm{NO}_{3}$ solution was injected uniformly into each pot using a four-needle injection technique, to give a final concentration of $30 \mathrm{mg} \mathrm{NH}_{4}{ }^{+}-\mathrm{N} \mathrm{kg}^{-1}$ soil and $30 \mathrm{mg} \mathrm{NO}_{3}{ }^{-} \mathrm{N} \mathrm{kg}^{-1}$ soil. At $0.5,24,48,72 \mathrm{~h}$ after addition of ${ }^{15} \mathrm{~N}$ labeled solutions, soil and whole plant were collected. $\mathrm{NH}_{4}{ }^{+}$and $\mathrm{NO}_{3}{ }^{-}$in soil were extracted using $1 \mathrm{M}$ potassium chloride solution $(\mathrm{KCl})$ at a solution:soil ratio of 5:1 to determine their concentrations and ${ }^{15} \mathrm{~N}$ abundances. All plants were soaked in $1 \mathrm{M} \mathrm{KCl}$ solution for five minutes to remove residual inorganic $\mathrm{N}$, and thoroughly rinsed with deionized water. Plant samples were then deenzymed at $105^{\circ} \mathrm{C}$ for $0.5 \mathrm{~h}$, dried at $80^{\circ} \mathrm{C}$ to a constant weight, grinded, and passed through a $0.15 \mathrm{~mm}$ sieve to measure the $\mathrm{N}$ concentrations and ${ }^{15} \mathrm{~N}$ abundances. In addition, soil pH, dissolved organic $\mathrm{C}(\mathrm{DOC})$ concentration, the abundances of bacteria, fungi, ammonia-oxidizing archaea (AOA) and ammonia-oxidizing bacteria (AOB) were also determined.

Analytical methods

Soil pH was measured in a 2.5:1 $(\mathrm{v} / \mathrm{w})$ water/soil ratio using a DMP-2mV/pH detector (Quark Ltd., Nanjing, China). Soil electrical conductivity (EC) was determined by a conductivity detector (Kang Yi Crops., Nanjing, China) at a 5:1 ( $v / w)$ water/soil ratio. Soil organic carbon (SOC) was analyzed by wet digestion with $\mathrm{H}_{2} \mathrm{SO}_{4}-\mathrm{K}_{2} \mathrm{Cr}_{2} \mathrm{O}_{7}$ and total $\mathrm{N}$ (TN) was determined by semi-micro Kjeldahl digestion using Se, $\mathrm{CuSO}_{4}$, and $\mathrm{K}_{2} \mathrm{SO}_{4}$ as catalysts. Soil dissolved organic $\mathrm{C}$ (DOC) was extracted with $1 \mathrm{M} \mathrm{KCl}$ solution in a $5: 1 \mathrm{KCl}$ solution:soil ratio, and then measured using an Analyzer Multi N/C (Analytic Jena, Jena, Germany). Total soil phosphorus (TP) was determined with $\mathrm{NaOH}$ fusion and Mo-Sb colorimetry, available phosphorus (AP) with $\mathrm{NaHCO}_{3}$ digestion and Mo-Sb colorimetry, total potassium (TK) with $\mathrm{NaOH}$ fusion and flame photometer, as well as available kalium (AK) with $\mathrm{CH}_{3} \mathrm{COONH}_{4}$ digestion and flame photometer (for details see Bao 2000). The soil was extracted with $1 \mathrm{M} \mathrm{KCl}$ solution, and concentrations of $\mathrm{NH}_{4}{ }^{+}$and $\mathrm{NO}_{3}{ }^{-}$in the extracted solution were analyzed by an automated continuous flow wet chemistry analyzer (SA1000, Skalar, Netherlands). A micro-diffusion method with magnesium oxide and Devarda's alloy combining with oxalic acid absorption was used to separate $\mathrm{NH}_{4}{ }^{+}$and $\mathrm{NO}_{3}{ }^{-}$in the extracts. Subsequently, the ${ }^{15} \mathrm{~N}$ abundances of $\mathrm{NH}_{4}{ }^{+}$and $\mathrm{NO}_{3}{ }^{-}$were determined with an Isotope-Ratio Mass Spectrometry (IRMS) system (Europa Scientific Integra, Crewe, UK). Plant ${ }^{15} \mathrm{~N}$ abundance was analyzed using the IRMS system with a Finnigan Flash EA 1112 elemental analyzer (Thermo Scientific, Bremen, Germany).

DNA was extracted from $0.25 \mathrm{~g}$ fresh soil using the Power Soil DNA Isolation Kit (Bioer Technology Co., Ltd) according to the manufacturer's instructions. The qPCR (quantitative real-time polymerase chain reaction) amplifications were performed in eight-well tubes with a CFX96TM Real-Time System (Bio-Rad Laboratories Inc., Hercules, CA, USA). The abundances of bacteria (Eub338F/Eub518R), fungi (ITS1F/ ITS2R), AOA (Arch-amoAF/Arch-amoAR) and AOB (amoA1F/amoA2R) were measured using the primer sets and thermal conditions listed in Table S1 (Supporting information). The reaction mixture for bacteria, fungi, $A O A$ and $A O B$ was set according to Zhao et al. (2017). The standard curves were established according to Huang et al. (2015) and Zhao et al. (2017), and the amplification efficiencies for bacteria, fungi, AOA and AOB were $115 \%, 98 \%, 100 \%, 94 \%$ respectively. Amplification specificity was evaluated by melting-curve analysis and copy numbers were then converted to oven-dry basis.

The ${ }^{15} \mathrm{~N}$ tracing tool, Ntrace $_{\text {plant }}$, containing six $\mathrm{N}$ pools and twelve processes (Fig. 1), was used to simultaneously quantify soil gross transformation and plant $\mathrm{N}$ uptake rates (He et al. 2020). The Markov Chain Monte Carlo (MCMC) algorithm, able to calculate true parameter uncertainties, was used for data analysis. The misfit function in the model between the modeled and observed data $f(m)$ considers the variance of the individual observations (see eqt. 3 in (Müller et al. 2007)). The concentrations and ${ }^{15} \mathrm{~N}$ abundances of soil $\mathrm{NH}_{4}{ }^{+}, \mathrm{NO}_{3}{ }^{-}$, and plant $\mathrm{N}$ (mean \pm standard deviation) from two ${ }^{15} \mathrm{~N}$ labeled treatments were supplied to $\mathrm{Ntrace}$ plant. The average gross $\mathrm{N}$ transformation rates over the experimental period were quantified by simultaneously optimizing the kinetic parameters, set to zero-order, first-order, or Michaelis-Menten kinetics, by minimizing the misfit between the modeled and observed values, and expressed in units of $\mathrm{mg} \mathrm{N} \mathrm{kg}^{-1}$ soil d ${ }^{-1}$. The most suitable model was selected according to Akaikes Information Criterion (AIC) (Cox et al. 2006) within the MATLAB computing environment (Version 7, The MathWorks Inc.) (for details see He et al. 2020).

Due to the faster growth rate of cucumber than tomato, the $\mathrm{N}$ uptake rates of cucumber were higher than that of tomato, and thus, $\mathrm{NH}_{4}{ }^{+}$ and $\mathrm{NO}_{3}{ }^{-}$in soil planted with cucumber could not be detected at $72 \mathrm{~h}$ after addition of ${ }^{15} \mathrm{~N}$ labeled solution. Therefore, the data applied to the model included concentrations and ${ }^{15} \mathrm{~N}$ abundances of soil $\mathrm{NH}_{4}{ }^{+}, \mathrm{NO}_{3}{ }^{-}$, and plant $\mathrm{N}$ (mean \pm standard deviation) of three sets of data (i.e. $0.5,24,48 \mathrm{~h}$ ) in soil planted cucumber, while four sets of data $(0.5,24,48,72 \mathrm{~h}$ ) in soils planted with tomato and without plants.

Calculations and statistical analyses

Page $4 / 14$ 
Total gross $\mathrm{N}$ mineralization rates $(M)=M_{N / a b}+M_{N r e c}$

Total gross $\mathrm{NH}_{4}{ }^{+}$immobilization rates $\left(I_{N H 4}\right)=I_{N H 4 N l a b}+I_{N H 4 N r e c}$

Total gross nitrification rates $(M)=O_{N H 4}+O_{N r e c}$

Total gross microbial $\mathrm{N}$ immobilization rates $\left(I_{T N}\right)=I_{N H 4}+I_{N O 3}$

Total plant $\mathrm{N}$ uptake rates $\left(U_{T N}\right)=U_{N H 4}+U_{N O 3}$

where $M_{N l a b}=$ mineralization rate of labile organic $\mathrm{N}$ pool to $\mathrm{NH}_{4}{ }^{+}, M_{N r e c}=$ mineralization rate of recalcitrant organic $\mathrm{N}$ pool to $\mathrm{NH}_{4}{ }^{+}$, $I_{\text {NH4Nlab }}=$ immobilization rate of $\mathrm{NH}_{4}{ }^{+}$to labile organic $\mathrm{N} \mathrm{pool}, I_{\mathrm{NH} 4 \mathrm{Nrec}}=$ immobilization rate of $\mathrm{NH}_{4}{ }^{+}$to recalcitrant organic $\mathrm{N}$ pool, $I_{\mathrm{NO}}$ $=$ immobilization rate of $\mathrm{NO}_{3}{ }^{-}$to organic $\mathrm{N} \mathrm{pool}, \mathrm{O}_{\mathrm{NH} 4}=$ oxidation of $\mathrm{NH}_{4}{ }^{+}$to $\mathrm{NO}_{3}{ }^{-}, \mathrm{O}_{\mathrm{Nrec}}=$ oxidation of organic $\mathrm{N} \mathrm{pool}$ to $\mathrm{NO}_{3}{ }^{-}, \mathrm{U}_{\mathrm{NH} 4}=$ plant $\mathrm{NH}_{4}{ }^{+}$uptake rate, and $U_{\mathrm{NO}}=$ plant $\mathrm{NO}_{3}{ }^{-}$uptake rate.

Significant differences of each $\mathrm{N}$ transformation rate between means of CK, D15 and D26 in each treatment were estimated by one-way ANOVA (analysis of variance). Based on the actual experimental repetitions (three repetitions), SigmaPlot (Version 3.5) and Excel 2019 were used to calculate the LSD (least significant differences) at 0.05 significance level for each $\mathrm{N}$ transformation rate, which was the most conservative way to calculate LSDs (Müller et al. 2011). The T-test analysis was used to examine the differences in soil properties between studied two soils. The relationships among $\mathrm{N}$ transformation rates were examined using Spearman correlation analyses with two-sided tests.

\section{Results}

Soil properties

The two soils had comparable concentrations of DOC and $\mathrm{NH}_{4}{ }^{+}$, as well as abundances of bacteria before the start of the study (Table 1). Soil $\mathrm{pH}$ and $\mathrm{C} / \mathrm{N}$ were significantly lower in HS compared with LS. The EC, SOC, TN, TP and TK concentrations were on average $430.43 \mu \mathrm{S} \mathrm{cm}{ }^{-1}, 12.19 \mathrm{~g} \mathrm{~kg}^{-1}, 1.61 \mathrm{~g} \mathrm{~kg}^{-1}, 1.40 \mathrm{~g} \mathrm{~kg}^{-1}$ and $18.54 \mathrm{~g} \mathrm{~kg}^{-1}$, respectively in HS and were significantly higher than LS (on average $55.42 \mu \mathrm{S} \mathrm{cm}^{-1}, 6.73 \mathrm{~g} \mathrm{~kg}^{-1}, 0.76 \mathrm{~g} \mathrm{~kg}^{-1}, 0.52 \mathrm{~g} \mathrm{~kg}^{-1}$ and $16.88 \mathrm{~g} \mathrm{~kg}^{-1}$, respectively). The NO${ }_{3}^{-}, \mathrm{AP}$ and $\mathrm{AK}$ concentrations in HS were about 9.1, 10.0 and 2.3 times higher than LS. The abundances of fungi, AOA and AOB in HS were also significantly higher than LS.

The DOC concentrations significantly increased at D26 in HSC and LSC treatments (cucumber), while, decreased in HST and LST treatments (tomato) (Fig. 2a). Soil pH of CK was not different from D26, while it was slightly lower than in D15 in all treatments (Fig. 2b). There was no significant change in the abundances of bacteria and AOA in all treatments (Fig. 2c, e). The abundance of fungi was significantly higher in D15 and D26 than CK (Fig. 2d). Moreover, the abundance of fungi in D26 was higher than in D15, particularly in soils planted with cucumber. The abundance of AOB significantly decreased by the presence of plants, and decreased with planting time (Fig. 2f).

$\mathrm{NH}_{4}{ }^{+}$dynamics

Modeled and measured values of the concentrations and ${ }^{15} \mathrm{~N}$ abundances of soil $\mathrm{NH}_{4}{ }^{+}, \mathrm{NO}_{3}{ }^{-}$and plant $\mathrm{N}$ pools matched well (Fig. S1S4). The Ntrace analysis showed that soil gross $\mathrm{N}$ transformation rates were significantly affected by the presence of plants (Fig. 3 ), except for dissimilatory $\mathrm{NO}_{3}{ }^{-}$reduction to $\mathrm{NH}_{4}{ }^{+}$, release of adsorbed $\mathrm{NH}_{4}{ }^{+}$and adsorption of $\mathrm{NH}_{4}{ }^{+}$on cation exchange sites rates (data not shown, because they were close to zero).

Generally, there were no significant differences in total $\mathrm{N}$ mineralization rates $\left(M\right.$, mineralization rate of labile $\left(M_{N / a b}\right)$ and recalcitrant $\left(M_{N r e c}\right)$ organic $\mathrm{N}$ pool to $\mathrm{NH}_{4}^{+}$) between HS and LS in all treatments (Fig. 3a). In HST, $M_{N l a b}$ and $M_{N r e c}$ of D15 were none significantly lower compared to CK. In LST, no significant differences among CK, D15 and D26 in $M_{N / a b}$ were found, while the $M_{N r e c}$ of D26 was significantly higher than in CK and D15. In HSC and LSC, $M_{\text {Nlab }}$ was 5-128 times lower than in CK at D15 and D26, while $M_{\text {Nrec }}$ was 2-47 times higher than in CK at D15 and D26. Therefore, $M\left(M_{N l a b}+M_{N r e c}\right)$ was comparable between soils with (D15 and D26) and without (CK) planting in all treatments. 
For $\mathrm{CK}$, the total gross $\mathrm{NH}_{4}{ }^{+}$immobilization rate $\left(I_{N H 4}\right)$ in HS was significantly higher than in LS (Fig. 3b). $I_{N H 4}$ was negligible at D15 and D26, and significantly lower than CK $\left(0.39 \mathrm{mg} \mathrm{N} \mathrm{kg}^{-1} \mathrm{~d}^{-1}\right)$ in HST and HSC treatments. In LST and LSC treatments, the $I_{N H 4}$ of D15 was $3.35 \mathrm{mg} \mathrm{N} \mathrm{kg}^{-1} \mathrm{~d}^{-1}$ and $1.56 \mathrm{mg} \mathrm{N} \mathrm{kg}^{-1} \mathrm{~d}^{-1}$, respectively, and significantly higher than in CK and D26 where $I_{\mathrm{NH} 4}$ was less than 0.04 mg N $\mathrm{kg}^{-1} \mathrm{~d}^{-1}$; there were no significant differences in $I_{N H 4}$ between CK and D26.

\section{$\mathrm{NO}_{3}{ }^{-}$dynamics}

In the CK treatments, the rate of $\mathrm{NH}_{4}{ }^{+}$oxidation to $\mathrm{NO}_{3}{ }^{-}$(autotrophic nitrification, $\mathrm{O}_{\mathrm{NH} 4}$ ) was significantly higher in $\mathrm{HS}$ than in LS, and the rate of organic $\mathrm{N}$ oxidation to $\mathrm{NO}_{3}{ }^{-}$(heterotrophic nitrification, $\mathrm{O}_{\mathrm{Nrec}}$ ) was negligible in both soils (Fig. 3c). A significant decrease in $\mathrm{O}_{\mathrm{NH} 4}$ was found at D15 and D26 compared with CK in all treatments. $O_{N H 4}$ in D15 were 2, 2, 11, and 6 times lower than CK in the HST, LST, HSC and LSC treatments, respectively. At the same time, $O_{N H 4}$ decreased significantly in D26 compared to D15 in all treatments. The $O_{N H 4}$ decreased with decreasing the abundance of $\mathrm{AOB}(p<0.01)$ (Fig. 3d).

Interestingly, the other $\mathrm{NO}_{3}{ }^{-}$production pathway, oxidation of organic $\mathrm{N}$ to $\mathrm{NO}_{3}{ }^{-}\left(\mathrm{O}_{\mathrm{Nrec}}\right.$, heterotrophic nitrification), was stimulated by the presence of plants. $O_{N r e c}$ were all negligible in CK, and significantly increased to 2.81 and $2.43 \mathrm{mg} \mathrm{N} \mathrm{kg}^{-1} \mathrm{~d}^{-1}$ in the HSC and LSC treatments at D15, respectively. It increased to 0.51 and $0.1 \mathrm{mg} \mathrm{N} \mathrm{kg}^{-1} \mathrm{~d}^{-1}$ in HST and LST of D15, but was not significantly different from CK. At D26, a more significant stimulation of $O_{N r e c}$ occurred to rates of $2.00,3.79,8.11,2.99 \mathrm{mg} \mathrm{N} \mathrm{kg}^{-1} \mathrm{~d}^{-1}$, in HST, LST, HSC, LSC, respectively. $O_{\mathrm{Nrec}}$ was responsible for $5-97 \%$ of the total gross nitrification rates $\left(\mathrm{N}, \mathrm{O}_{\mathrm{NH} 4}+\mathrm{O}_{\mathrm{Nrec}}\right)$. $O_{\mathrm{Nrec}}$ was significantly positively correlated with the abundance of fungi $(p<0.05)$ and DOC $(p=0.06)$ (Fig. 4e, f).

The $\mathrm{NO}_{3}{ }^{-}$immobilization rate $\left(I_{\mathrm{NO}}\right)$ was negligible in $\mathrm{CK}$ of both HS and LS (Fig. 3b). In HST and LST treatments, there were no significant differences between soil without (CK) and with planting (D15 and D26) in $I_{N O 3}$. However, in HSC, $I_{N O 3}$ was significantly higher at D15 and D26 compared to CK, and significantly increased from $5.56 \mathrm{mg} \mathrm{N} \mathrm{kg}^{-1} \mathrm{~d}^{-1}$ at D15 to $10.84 \mathrm{mg} \mathrm{N} \mathrm{kg}^{-1} \mathrm{~d}^{-1}$ at D26. In the LSC treatment, $I_{\mathrm{NO}}$ was significantly higher in D15 than in CK and D26, and no significant difference was observed in $I_{\mathrm{NO}}$ between $\mathrm{CK}$ and D26.

Plant N uptake

The plant $\mathrm{NH}_{4}{ }^{+}$uptake rate $\left(U_{N H 4}\right)$ increased with planting duration, except in the HSC treatment where $U_{N H 4}$ was significantly higher in D15 than in D26 (Fig. 3d). The highest $U_{\mathrm{NH} 4}$ was found at D15 in HSC with an average of $6.46 \mathrm{mg} \mathrm{N} \mathrm{kg}^{-1} \mathrm{~d}^{-1}$. The lowest $U_{\mathrm{NH} 4}$ was in D15 in HST and LHS with 0.94 and $0.44 \mathrm{mg} \mathrm{N} \mathrm{kg}^{-1} \mathrm{~d}^{-1}$, respectively. Similarly, the plant $\mathrm{NO}_{3}{ }^{-}$uptake rate $\left(U_{N O 3}\right)$ also increased with planting duration, except in HSC where there was no significant difference between D15 and D26. The highest $U_{N O 3}$ was 13.29 mg $\mathrm{N}$ $\mathrm{kg}^{-1} \mathrm{~d}^{-1}$ at D26 of LSC. The $U_{N O 3}$ was $7.5,17.0,1.0,3.4$ times higher than $U_{N H 4}$ in D15, and 2.0, 2.9, 1.4, 4.9 times higher than $U_{N H 4}$ in D26 in the HST, LST, HSC and LSC treatments, respectively. This was consistent with the $\mathrm{NO}_{3}{ }^{-}$-preference of tomatoes and cucumber. Although, $U_{N H 4}$ was responsible for $12 \%, 6 \%, 49 \%$ and $23 \%$ of total $N$ uptake in $\mathrm{D} 15$, and $34 \%, 26 \%, 41 \%$ and $17 \%$ of total $\mathrm{N}$ uptake in D26 in the HST, LST, HSC and LSC treatments, respectively.

The $U_{N H 4}$ was significantly and positively related to $M_{N r e c}(p<0.05)$ (Fig. 4a), while negatively related to $I_{N H 4}(p<0.05)$ and $O_{N H 4}(p<$ 0.05 ) (Fig. 4b, c). A significantly positive relationship exists between the $U_{N O 3}+I_{N O 3}$ and $O_{N r e c}(p<0.01)$, and between $U_{T N}+I_{T N}$ and $M+$ $O_{\mathrm{Nrec}}$ (Fig. $4 \mathrm{~g}, \mathrm{i}$ ). The rate of $I_{\mathrm{NO}}$ and $U_{\mathrm{NO} 3}$ were negatively correlated with each other (i.e. an increasing $I_{\mathrm{NO} 3}$ and decreasing $U_{\mathrm{NO} 3}$ ) $(p<0.05)$ (Fig. 4h).

\section{Discussion}

Consistent with our hypothesis we observed significant feedbacks between vegetable $\mathrm{N}$ uptake and soil $\mathrm{N}$ transformations, irrespectively whether or not $\mathrm{N}$ accumulation occurred. The studied vegetables with $\mathrm{NO}_{3}{ }^{-}$preference also assimilated a considerable quantity of $\mathrm{NH}_{4}{ }^{+}$, while soil did not supply additional $\mathrm{NH}_{4}^{+}$via $\mathrm{N}$ mineralization, resulting in a reduction of $\mathrm{NH}_{4}{ }^{+}$immobilization and $\mathrm{NH}_{4}{ }^{+}$oxidation (autotrophic nitrification rate). Under conditions where $\mathrm{NO}_{3}{ }^{-}$production via autotrophic nitrification alone did not meet vegetables $\mathrm{NO}_{3}{ }^{-}$ demand a stimulation of $\mathrm{NO}_{3}{ }^{-}$production via heterotrophic nitrification occurred, which was not consistent with our hypothesis that 
vegetables with a $\mathrm{NO}_{3}{ }^{-}$preference would stimulate autotrophic nitrification to meet their $\mathrm{NO}_{3}{ }^{-}$demand. However it was in line with results by (He et al. 2022).

Soil N mineralization is the primary source of soil available N. In this study, there were no significant differences in total gross $\mathrm{N}$ mineralization rates with respect to the presence or absence of plants, because gross mineralization rates of specific organic $\mathrm{N}$ pools (i.e. labile and recalcitrant organic $\mathrm{N}$ pool) responded in an opposite way to plants (Fig. 3a). Soil labile organic $\mathrm{N}$ substrate may be reduced in the presence of plants, via uptake of small-molecular labile organic $\mathrm{N}$ (such as amino acids and urea) in the rhizosphere by plants and microorganisms (Cao et al. 2015; Gioseffi et al. 2012; Kielland 1994). As a result, $\mathrm{NH}_{4}{ }^{+}$production via mineralization of labile organic $\mathrm{N}$ pool to $\mathrm{NH}_{4}{ }^{+}\left(M_{N l a b}\right)$ was inhibited. However, we found that $M_{\text {Nrec }}$ significantly increased in the presence of plants, particularly in soils planted with cucumber which are known for their large $\mathrm{NO}_{3}{ }^{-}$uptake requirements (Hutchinson and Miller 1912). Furthermore, there was a significant and positive relationship between $M_{N r e c}$ and plant $\mathrm{NH}_{4}{ }^{+}$uptake $(p<0.05)$ (Fig. 4a). The compounds exuded by plant roots can provide C source for the microorganisms, driving N mining (Kuzyakov and Xu 2013; Meier et al. 2017), in particular by breaking down recalcitrant organic matter (Biernath et al. 2008; Hill et al. 2012). This was accompanied by a stimulation of $M_{\text {Nreo }}$ being consistent with previous reports where $M_{N r e c}$ was almost the unique pathway for $\mathrm{NH}_{4}{ }^{+}$production in the presence of plants $(\mathrm{He}$ et al. 2021).

In the present study, autotrophic nitrification rates significantly decreased with time of plant growth (Fig. 3c), indicating that presence of vegetables (even $\mathrm{NO}_{3}{ }^{-}$-preference) did inhibit autotrophic nitrification rates. Our results found that there were no significant differences in gross $\mathrm{N}$ mineralization rate between presence and absence of plants, indicating that soil in the presence of plants failed to supply more $\mathrm{NH}_{4}{ }^{+}$via gross $\mathrm{N}$ mineralization to autotrophic nitrification. In the plant-soil system, $\mathrm{NH}_{4}{ }^{+}$is not only the substrate of autotrophic nitrification, but also the $\mathrm{N}$ source for plants and microorganisms (Hodge et al. 2000; Inselsbacher et al. 2010; Kuzyakov and Xu 2013). We observed that autotrophic nitrification rate significantly decreased with increasing plant $\mathrm{NH}_{4}{ }^{+}$uptake rate $(p<0.05)(\mathrm{Fig}$. 4c). In spite of the $\mathrm{NO}_{3}{ }^{-}$-preference nature of studied plants (tomato and cucumber) (Al-Harbi 1995), the plant $\mathrm{NH}_{4}{ }^{+}$uptake rate was responsible for $6 \%-49 \%$ of total $\mathrm{N}$ uptake rates in all treatments. One of possible reasons were to maintain a suitable ionic balance in plant, therefore also $\mathrm{NH}_{4}{ }^{+}$is required for $\mathrm{NO}_{3}{ }^{-}$preference plants. To keep $\mathrm{NH}_{4}{ }^{+}$at a certain level it makes then sense that $\mathrm{NH}_{4}{ }^{+}$oxidation is inhibited, while $\mathrm{NO}_{3}{ }^{-}$is generated via organic $\mathrm{N}$ oxidation rather than $\mathrm{NH}_{4}{ }^{+}$oxidation. The assimilation of $\mathrm{NH}_{4}{ }^{+}$by plants could reduce the $\mathrm{NH}_{4}{ }^{+}$ substrates, and further inhibited autotrophic nitrification. Furthermore, plant $\mathrm{NH}_{4}^{+}$uptake rate (average $3.13 \mathrm{mg} \mathrm{N} \mathrm{kg}^{-1} \mathrm{~d}^{-1}$ ) was higher than microbial $\mathrm{NH}_{4}{ }^{+}$immobilization (average $0.62 \mathrm{mg} \mathrm{N} \mathrm{kg}^{-1} \mathrm{~d}^{-1}$ ), indicating that plants are stronger competitors for $\mathrm{NH}_{4}^{+}$than microorganisms (Schimel and Bennett 2004). This likely lead to a decrease in the abundance of microorganisms, as observed in our study in the presence of plants (Fig. 2f). AOB rather than the AOA carried out autotrophic nitrification, despite a higher AOA than $A O B$ abundance in greenhouse soil (Di et al. 2009), being in line with our results. Thus, the reduction of abundance of AOB was likely be responsible for lower autotrophic nitrification rates in the presence of plants. This was strongly supported by a significant positive relationship between autotrophic nitrification rate and abundance of $\mathrm{AOB}(p<0.01)$ (Fig. $4 \mathrm{~d})$. The autotrophic nitrification rate $(1.11 \mathrm{mg} \mathrm{N}$ $\left.\mathrm{kg}^{-1} \mathrm{~d}^{-1}\right)$ was much lower than plant $\mathrm{NO}_{3}^{-}$uptake rate $\left(8.29 \mathrm{mg} \mathrm{N} \mathrm{kg}^{-1} \mathrm{~d}^{-1}\right)$ in the presence of plants, indicating that $\mathrm{NO}_{3}{ }^{-}$production via autotrophic nitrification alone failed to meet plants $\mathrm{NO}_{3}{ }^{-}$requirement.

Our results showed that the rate of heterotrophic nitrification was significantly enhanced by the presence of plants (Fig. 4c), accounting for $5 \%-97 \%$ of total $\mathrm{NO}_{3}{ }^{-}$yield. We found that plant $\mathrm{NO}_{3}{ }^{-}$uptake rate and microbial $\mathrm{NO}_{3}{ }^{-}$immobilization rate were significantly positively related to heterotrophic nitrification rate $(p<0.01)$ (Fig. $4 \mathrm{~g})$. Furthermore, plant $\mathrm{N}$ uptake rate and microbial $\mathrm{N}$ immobilization rate were not significantly correlated with gross $\mathrm{N}$ mineralization rates, while they were significantly and positively related to total inorganic $\mathrm{N}$ production rates (i.e. gross $\mathrm{N}$ mineralization rate + heterotrophic nitrification rate) $(p<0.05)$ (Fig. 4i). These results indicated that heterotrophic nitrification played a vital role to provide available $\mathrm{N}$ for plants in plant-soil systems. Heterotrophic nitrification is regulated by a number of factors, including pH, SOC, C/N ratio, DOC, microorganisms (He et al. 2020; He et al. 2021; Zhang et al. 2014; Zhang et al. 2020; Zhang et al. 2019; Zhu et al. 2015). In our study, soil SOC, C/N ratio, and pH did not change significantly during the experimental duration. We found that DOC concentrations and the abundance of fungi significantly increased during plant growth and were related to heterotrophic nitrification rates (Fig. 4e, f). Thus, plant activity on microorganisms is able to stimulate heterotrophic nitrification in the observed plant-soil systems. Compounds exuded by plant roots were not only bioavailable $\mathrm{C}$ and $\mathrm{N}$ substrates, but also provided signaling substances regulating the activities of heterotrophic microorganisms, such as fungi and heterotrophic bacteria participating in heterotrophic nitrification (Eylar and Schmidt 1959; Haichar et al. 2014; Padje et al. 2016; Schmidt 1954). Fungi were the dominating microorganism carrying out heterotrophic nitrification in acid soil (Zhu et al. 2015), but previous studies have also reported 
that fungi isolated from acid soils are also capable of nitrification under alkaline conditions (De Boer and Kowalchuk 2001; Lang and Jagnow 1986). We also found a significantly positive relationship between $O_{N r e c}$ and the abundance of fungi $(p<0.05)$. Thus, plant activity and heterotrophic microorganisms in rhizosphere rather than soil reaction affected heterotrophic nitrification in studied soils.

Another observation was that microbial $\mathrm{N}$ immobilization rates were significantly affected by the presence of plants, whether $\mathrm{N}$ accumulation occurred or not. Our results showed that the microbial $\mathrm{NH}_{4}{ }^{+}$immobilization rates were reduced by the presence of plants, except in D15 of LST and LSC treatments (Fig. 3b). Plant $\mathrm{NH}_{4}{ }^{+}$uptake rates were negatively correlated with microbial $\mathrm{NH}_{4}{ }^{+}$ immobilization rates $(p<0.05$ ) (Fig. $4 b)$ indicating that plants possessed a stronger competitive capacity for $\mathrm{NH}_{4}^{+}$than microorganisms. Therefore, plant $\mathrm{NH}_{4}{ }^{+}$uptake reduced $\mathrm{NH}_{4}{ }^{+}$concentration in soils, and further limited microbial $\mathrm{NH}_{4}{ }^{+}$immobilization. Bioavailable organic $\mathrm{C}$ root exudates could stimulate microbial N assimilation (Cheng and Gershenson 2007; Singh et al. 2004) explaining enhanced $\mathrm{NH}_{4}{ }^{+}$immobilization rate in presence of plants, as observed in D15 of LST and LSC. We observed that $\mathrm{NO}_{3}{ }^{-}$immobilization rates in the presence of plants significantly increased in soils especially with cucumber (i.e. HSC and LSC treatments), while they were negligible and similar to CK in soils planted with tomato (i.e. HST and LST treatments). Previous studies have shown that the $\mathrm{NO}_{3}{ }^{-}$immobilization rates in greenhouse soil with long-term chemical fertilizer application is weak, likely due to low SOC and C/N ratio (Cao et al. 2021; Cheng et al. 2017; Wang et al. 2021). This probably led to negligible $\mathrm{NO}_{3}{ }^{-}$immobilization rate of CK. Despite that root exudates provided bioavailable $\mathrm{C}$ for microbial $\mathrm{N}$ assimilation, faster plant $\mathrm{NO}_{3}{ }^{-}$uptake rate reduced the $\mathrm{NO}_{3}{ }^{-}$concentration in soil, and further inhibited the $\mathrm{NO}_{3}{ }^{-}$immobilization rates, as observed in $\mathrm{HST}$ and LST. In this study, $\mathrm{NO}_{3}{ }^{-}$immobilization rates include microbial $\mathrm{NO}_{3}{ }^{-}$immobilization rates and denitrification rate. Compared with tomato, cucumber with a well-developed root system (Figure. S5) consumed more $\mathrm{O}_{2}$ for root respiration, an in turn enhanced soil anaerobicity, which inhibited plant $\mathrm{N}$ uptake (Nichols et al. 2001). Thus, anaerobic conditions in combination with high- $\mathrm{NO}_{3}{ }^{-}$was most likely responsible for denitrification in soil (Knowles 1982). Therefore, the increase of $\mathrm{NO}_{3}{ }^{-}$ immobilization rates was probably associated with increasing denitrification rate which could not be distinguished with the current version of the Ntrace $_{\text {plant }}$ tool causing enhanced $\mathrm{NO}_{3}{ }^{-}$consumption which may have limited plant $\mathrm{NO}_{3}{ }^{-}$uptake. This was further confirmed by plant $\mathrm{NO}_{3}{ }^{-}$uptake rate diminishing gradually with increasing $\mathrm{NO}_{3}{ }^{-}$immobilization rates $(p<0.05)$ (Fig. 4h).

\section{Conclusions}

Our results highlighted that there were significant feedbacks between vegetable $\mathrm{N}$ uptake and soil gross $\mathrm{N}$ transformation rates, whether or not $\mathrm{N}$ accumulation occurred in soils. Despite that the studied vegetables preferred $\mathrm{NO}_{3}{ }^{-}$, they still possessed a stronger competitive capacity for $\mathrm{NH}_{4}{ }^{+}$than microorganisms, resulting in the reduction of $\mathrm{NH}_{4}{ }^{+}$immobilization rate and autotrophic nitrification rate. Due to the low autotrophic nitrification rate in the presence of plant, heterotrophic nitrification was stimulated by $\mathrm{NO}_{3}{ }^{-}$-preference plants to become an important supply pathway of $\mathrm{NO}_{3}{ }^{-}$. Therefore, the management of organic $\mathrm{N}$ fertilizer for greenhouse cultivation with $\mathrm{NO}_{3}{ }^{-}$preference plants (such as tomato and cucumber) should take these results into account to enhance the capacity of $\mathrm{NO}_{3}{ }^{-}$production via heterotrophic nitrification. Whether strong feedbacks of plant $\mathrm{N}$ acquisition and soil $\mathrm{N}$ transformations in soils exist under high $\mathrm{N}$ accumulation should be confirmed in further studies when different plants and soils are studied.

\section{Declarations}

\section{Acknowledgements}

This work was supported by the National Natural Science Foundation of China [grant number 41830642, and U20A20107], the CAS Interdisciplinary Innovation Team project [grant number JCTD-2018-06], and the "Double World-Classes" Development in Geography project. The study was carried out as part of the IAEA funded coordinated research project "Minimizing farming impacts on climate change by enhancing carbon and nitrogen capture and storage in Agro-Ecosystems (D1.50.16)" and was carried out in close collaboration with the German Science Foundation research unit DASIM (FOR 2337).

\section{Declarations of interest: none}

\section{References}

1. Al-Harbi AR (1995) Growth and nutrient composition of tomato and cucumber seedlings as affected by sodium chloride salinity and supplemental calcium. J Plant Nutr 18:1403-1416 
2. Albornoz F (2016) Crop responses to nitrogen overfertilization: A review. Sci Hort 205:79-83. doi: 10.1016/j.scienta.2016.04.026

3. Bao S (2000) Soil and agricultural chemistry analysis. China agriculture press, Beijing

4. Biernath $\mathrm{C}$, Fischer $\mathrm{H}$, Kuzyakov $\mathrm{Y}$ (2008) Root uptake of $\mathrm{N}$-containing and $\mathrm{N}$-free low molecular weight organic substances by maize: A 14C/15N tracer study. Soil Biol Biochem 40:2237-2245. doi: 10.1016/j.soilbio.2008.04.019

5. Cao X, Wu L, Ma Q, Jin Q (2015) Advances in studies of absorption and utilization of amino acids by plants: A review.Yingyong Shengtai Xuebao26

6. Cao Y, He Z, Zhu T, Zhao F (2021) Organic-C quality as a key driver of microbial nitrogen immobilization in soil: A meta-analysis. Geoderma 383:114784. doi: 10.1016/j.geoderma.2020.114784

7. Cheng W, Gershenson A (2007) Carbon fluxes in the rhizosphere. The Rhizosphere. Elsevier

8. Cheng Y, Wang J, Wang J, Chang SX, Wang S (2017) The quality and quantity of exogenous organic carbon input control microbial NO3- immobilization: A meta-analysis. Soil Biol Biochem 115:357-363. doi: 10.1016/j.soilbio.2017.09.006

9. Congreves KA, Van Eerd LL (2015) Nitrogen cycling and management in intensive horticultural systems. Nutr Cycl Agrosyst 102:299-318. doi: 10.1007/s10705-015-9704-7

10. Cox G, Gibbons J, Wood A, Craigon J, Ramsden S, Crout N (2006) Towards the systematic simplification of mechanistic models. Ecol Model 198:240-246

11. Cuesta R (2019) Cuesta Roble releases 2019 global greenhouse statistics

12. De Boer W, Kowalchuk GA (2001) Nitrification in acid soils: micro-organisms and mechanisms. Soil Biol Biochem 33:853-866. doi: https://doi.org/10.1016/S0038-0717(00)00247-9

13. Di HJ, Cameron KC, Shen J-P, Winefield CS, O'Callaghan M, Bowatte S, He J-Z (2009) Nitrification driven by bacteria and not archaea in nitrogen-rich grassland soils. Nat Geosci 2:621-624

14. Eylar OR, Schmidt EL (1959) A survey of heterotrophic micro-organisms from soil for ability to form nitrite and nitrate. J Gen Microbiol 20:473-481

15. Fei C, Zhang S, Liang B, Li J, Jiang L, Xu Y, Ding X (2018) Characteristics and correlation analysis of soil microbial biomass phosphorus in greenhouse vegetable soil with different planting years. Acta Agric Boreali-sinica 33:195

16. Gioseffi E, Neergaard Ad, Schjørring JK (2012) Interactions between uptake of amino acids and inorganic nitrogen in wheat plants. Biogeosciences 9:1509-1518

17. Guo JH, Liu XJ, Zhang Y, Shen JL, Han WX, Zhang WF, Christie P, Goulding K, Vitousek PM, Zhang F (2010) Significant acidification in major Chinese croplands. science 327: 1008-1010

18. Haichar FeZ, Santaella C, Heulin T, Achouak W (2014) Root exudates mediated interactions belowground. Soil Biol Biochem 77:6980. doi: https://doi.org/10.1016/j.soilbio.2014.06.017

19. He X, Chi Q, Cai Z, Cheng Y, Zhang J, Müller C (2020) ${ }^{15} \mathrm{~N}$ tracing studies including plant $\mathrm{N}$ uptake processes provide new insights on gross $N$ transformations in soil-plant systems. Soil Biol Biochem 141:107666. doi: https://doi.org/10.1016/j.soilbio.2019.107666

20. He X, Chi Q, Meng L, Zhao C, He M, Dan X, Huang X, Zhao J, Cai Z, Zhang J, Müller C (2022) Plants with nitrate preference can regulate nitrification to meet their nitrate demand. Soil Biol Biochem 165:108516

21. He X, Chi Q, Zhao C, Cheng Y, Huang X, Zhao J, Cai Z, Zhang J, Müller C (2021) Plants with an ammonium preference affect soil N transformations to optimize their N acquisition. Soil Biol Biochem 155:108158. doi: 10.1016/j.soilbio.2021.108158

22. Hill PW, Farrell M, Jones DL (2012) Bigger may be better in soil N cycling: does rapid acquisition of small L-peptides by soil microbes dominate fluxes of protein-derived $\mathrm{N}$ in soil? Soil Biol Biochem 48:106-112

23. Hodge A, Robinson D, Fitter A (2000) Are microorganisms more effective than plants at competing for nitrogen? Trends in plant science. 5:304-308

24. Huang XQ, Wen T, Zhang JB, Meng L, Zhu TB, Liu LL, Cai ZC (2015) Control of soil-borne pathogen Fusarium oxysporum by biological soil disinfestation with incorporation of various organic matters. Eur J Plant Pathol 143:223-235. doi: 10.1007/s10658015-0676-x

25. Hutchinson HB, Miller NHJ (1912) The direct assimilation of inorganic and organic forms of nitrogen by higher plants. J Agric Sci 4:282-302

26. Inselsbacher E, Umana NH-N, Stange FC, Gorfer M, Schüller E, Ripka K, Zechmeister-Boltenstern S, Hood-Novotny R, Strauss J, Wanek W (2010) Short-term competition between crop plants and soil microbes for inorganic $\mathrm{N}$ fertilizer. Soil Biol Biochem 42:360372

Page 9/14 
27. Kielland K (1994) Amino acid absorption by arctic plants: implications for plant nutrition and nitrogen cycling. Ecology 75:23732383

28. Knowles R (1982) Denitrification. Microbiological reviews 46: 43-70

29. Kuzyakov $Y, X u X$ (2013) Competition between roots and microorganisms for nitrogen: mechanisms and ecological relevance. New Phytol 198:656-669. doi: 10.1111/nph.12235

30. Lang E, Jagnow G (1986) Fungi of a forest soil nitrifying at low pH values. FEMS Microbiol Lett 38:257-265. doi: 10.1111/j.15746968.1986.tb01736.x

31. Li J, Liu H, Wang H, Luo J, Zhang X, Liu Z, Zhang Y, Zhai L, Lei Q, Ren T, Li Y, Bashir MA (2018) Managing irrigation and fertilization for the sustainable cultivation of greenhouse vegetables. Agric Water Manage 210:354-363. doi: 10.1016/j.agwat.2018.08.036

32. Müller C, Laughlin RJ, Christie P, Watson CJ (2011) Effects of repeated fertilizer and cattle slurry applications over 38 years on N dynamics in a temperate grassland soil. Soil Biol Biochem 43:1362-1371

33. Müller C, Rütting T, Kattge J, Laughlin R, Stevens R (2007) Estimation of parameters in complex $15 \mathrm{~N}$ tracing models by Monte Carlo sampling. Soil Biol Biochem 39:715-726

34. Meier IC, Finzi AC, Phillips RP (2017) Root exudates increase $\mathrm{N}$ availability by stimulating microbial turnover of fast-cycling $\mathrm{N}$ pools. Soil Biol Biochem 106:119-128. doi: 10.1016/j.soilbio.2016.12.004

35. Min J, Lu K, Sun H, Xia L, Zhang H, Shi W (2016) Global Warming Potential in an Intensive Vegetable Cropping System as Affected by Crop Rotation and Nitrogen Rate. CLEAN - Soil, Air, Water 44:766-774. doi: 10.1002/clen.201400785

36. Min J, Sun H, Kronzucker HJ, Wang Y, Shi W (2021) Comprehensive assessment of the effects of nitrification inhibitor application on reactive nitrogen loss in intensive vegetable production systems. Agric Ecosyst Environ 307:107227

37. Nacry P, Bouguyon E, Gojon A (2013) Nitrogen acquisition by roots: physiological and developmental mechanisms ensuring plant adaptation to a fluctuating resource. Plant Soil 370:1-29. doi: 10.1007/s11104-013-1645-9

38. Nichols M, Woolley D, Christie C (2001) Effect of oxygen and carbon dioxide concentration in the root zone on the growth of vegetables. International Symposium on Design and Environmental Control of Tropical and Subtropical Greenhouses 578

39. Padje Avt, Whiteside MD, Kiers ET (2016) Signals and cues in the evolution of plant-microbe communication. Curr Opin Plant Biol 32:47-52. doi: https://doi.org/10.1016/j.pbi.2016.06.006

40. Ren T, Christie P, Wang J, Chen Q, Zhang F (2010) Root zone soil nitrogen management to maintain high tomato yields and minimum nitrogen losses to the environment. Sci Hort 125:25-33. doi: 10.1016/j.scienta.2010.02.014

41. Schimel JP, Bennett J (2004) Nitrogen mineralization: challenges of a changing paradigm. Ecology 85:591-602

42. Schmidt EL (1954) Nitrate formation by a soil fungus. Science 119:187-189

43. Singh BK, Millard P, Whiteley AS, Murrell JC (2004) Unravelling rhizosphere-microbial interactions: opportunities and limitations. Trends Microbiol 12:386-393

44. Subbarao G, Nakahara K, Ishikawa T, Ono H, Yoshida M, Yoshihashi T, Zhu Y, Zakir H, Deshpande S, Hash C (2013) Biological nitrification inhibition (BNI) activity in sorghum and its characterization. Plant Soil 366:243-259

45. Subbarao GV, Yoshihashi T, Worthington M, Nakahara K, Ando Y, Sahrawat KL, Rao IM, Lata JC, Kishii M, Braun HJ (2015) Suppression of soil nitrification by plants. Plant Sci 233:155-164. doi: 10.1016/j.plantsci.2015.01.012

46. Sun L, Lu Y, Yu F, Kronzucker HJ, Shi W (2016) Biological nitrification inhibition by rice root exudates and its relationship with nitrogen-use efficiency. New Phytol 212:646-656

47. Sun X, Liang B, Wang J, Cheng Y, Chang SX, Cai Z-C, Müller C, Zhang J-B (2020) Soil N transformation rates are not linked to fertilizer N losses in vegetable soils with high N input. Soil Tillage Res 202:104651. doi: 10.1016/j.still.2020.104651

48. Ti C, Luo Y, Yan X (2015) Characteristics of nitrogen balance in open-air and greenhouse vegetable cropping systems of China. Environ Sci Pollut Res Int 22:18508-18518. doi: 10.1007/s11356-015-5277-x

49. Wang J, Chen Z, Xu C, Elrys AS, Shen F, Cheng Y, Chang SX (2021) Organic amendment enhanced microbial nitrate immobilization with negligible denitrification nitrogen loss in an upland soil. Environ Pollut 288:117721. doi: 10.1016/j.envpol.2021.117721

50. Wang X, Zou C, Gao X, Guan X, Zhang W, Zhang Y, Shi X, Chen X (2018) Nitrous oxide emissions in Chinese vegetable systems: A meta-analysis. Environ Pollut 239:375-383. doi: 10.1016/j.envpol.2018.03.090

51. Waring BG, Álvarez-Cansino L, Barry KE, Becklund KK, Dale S, Gei MG, Keller AB, Lopez OR, Markesteijn L, Mangan S (2015) Pervasive and strong effects of plants on soil chemistry: a meta-analysis of individual plant 'Zinke'effects. Proceedings of the Royal Society B: Biological Sciences 282: 20151001

Page 10/14 
52. Zhang J, Cai Z, Müller C (2018) Terrestrial N cycling associated with climate and plant-specific N preferences: a review. Eur J Soil Sci 69:488-501. doi: 10.1111/ejss. 12533

53. Zhang J, Sun W, Zhong W, Cai Z (2014) The substrate is an important factor in controlling the significance of heterotrophic nitrification in acidic forest soils. Soil Biol Biochem 76:143-148. doi: 10.1016/j.soilbio.2014.05.001

54. Zhang Y, Dai S, Huang X, Zhao Y, Zhao J, Cheng Y, Cai Z, Zhang J (2020) pH-induced changes in fungal abundance and composition affects soil heterotrophic nitrification after 30 days of artificial pH manipulation. Geoderma 366:114255

55. Zhang Y, Wang J, Dai S, Zhao J, Huang X, Sun Y, Chen J, Cai Z, Zhang J (2019) The effect of C: N ratio on heterotrophic nitrification in acidic soils. Soil Biol Biochem 137:107562

56. Zhao J, Li Y, Wang B, Huang X, Yang L, Lan T, Zhang J, Cai Z (2017) Comparative soil microbial communities and activities in adjacent Sanqi ginseng monoculture and maize-Sanqi ginseng systems. Appl Soil Ecol 120:89-96. doi: 10.1016/j.apsoil.2017.08.002

57. Zhou J, Gu B, Schlesinger WH, Ju X (2016) Significant accumulation of nitrate in Chinese semi-humid croplands. Sci Rep 6:1-8

58. Zhu T, Meng T, Zhang J, Zhong W, Müller C, Cai Z (2015) Fungi-dominant heterotrophic nitrification in a subtropical forest soil of China. J Soils Sediments 15:705-709

59. Zhu T, Zhang J, Cai Z, Müller C (2011) The N transformation mechanisms for rapid nitrate accumulation in soils under intensive vegetable cultivation. J Soils Sediments 11:1178-1189. doi: 10.1007/s11368-011-0384-x

\section{Figures}

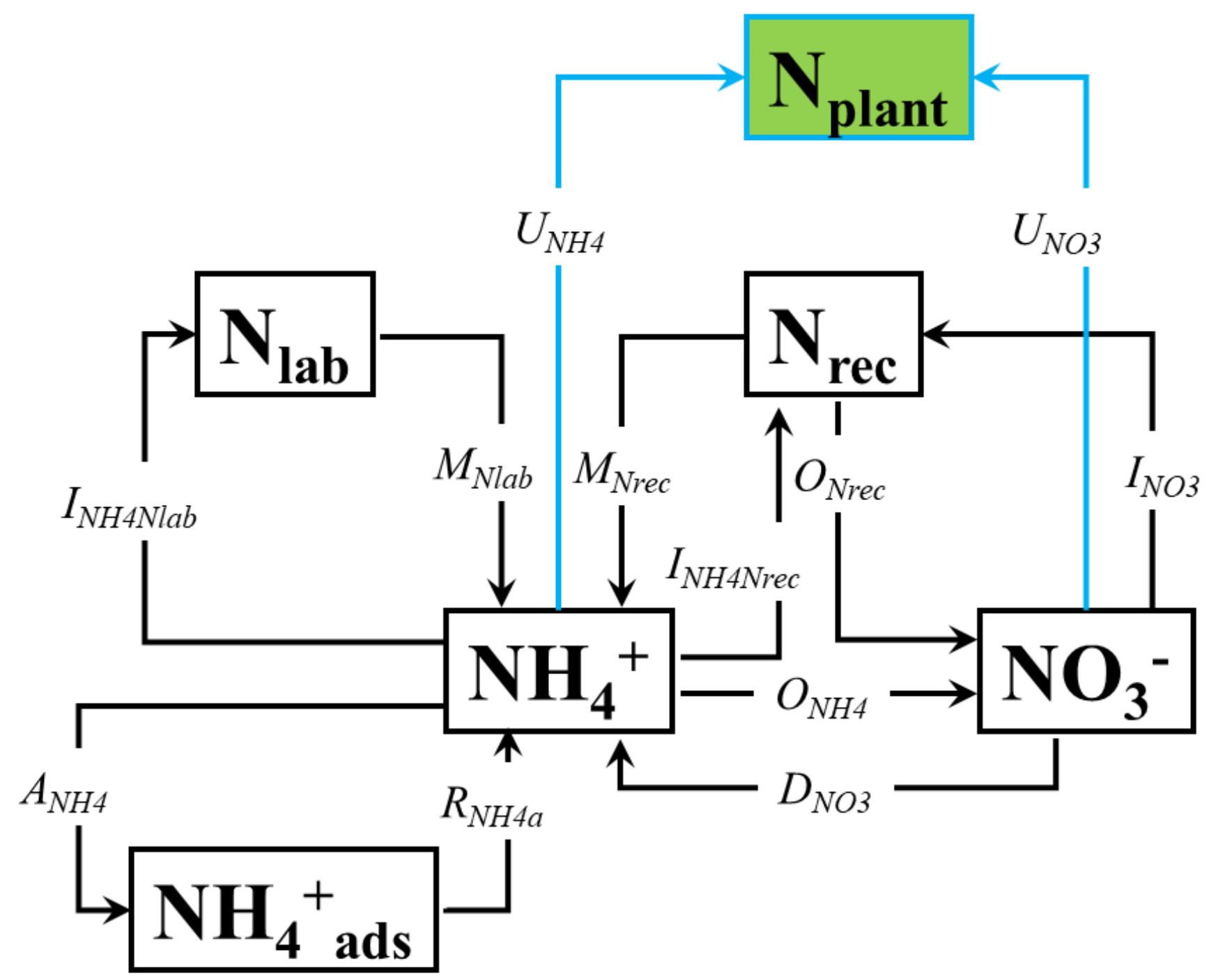

Figure 1 
$N_{\text {plant }}$, plant $\mathrm{N}$ pool; $\mathrm{N}_{\text {lab }}$, labile soil organic $\mathrm{N} ; \mathrm{N}_{\text {reo }}$ recalcitrant soil organic $\mathrm{N} ; \mathrm{NH}_{4}{ }^{+}$, ammonium; $\mathrm{NO}_{3}{ }_{3}$, nitrate; $\mathrm{NH}_{4}{ }^{+}$ads, adsorbed $\mathrm{NH}_{4}{ }^{+}$; $M_{N / a b}$, mineralization of labile organic $\mathrm{N}(\mathrm{Nlab})$ to $\mathrm{NH}_{4}{ }^{+} ; \mathrm{M}_{\text {Nreo }}$ mineralization of recalcitrant organic $\mathrm{N}(\mathrm{Nrec})$ to $\mathrm{NH}_{4}{ }^{+} ; I_{\mathrm{NH} 4 \mathrm{Nlab}}$, immobilization of $\mathrm{NH}_{4}{ }^{+}$to $\mathrm{Nlab}$; I $I_{\mathrm{NH} \text { Nreo }}$ immobilization of $\mathrm{NH}_{4}{ }^{+}$to $\mathrm{NreC}, \mathrm{R}_{\mathrm{NH} 4 a}$, release of adsorbed $\mathrm{NH}_{4}{ }^{+} ; A_{\mathrm{NH} 4}$, adsorption of $\mathrm{NH}_{4}{ }^{+}$on cation exchange sites; $\mathrm{O}_{\mathrm{NH} 4}$ oxidation of $\mathrm{NH}_{4}{ }^{+}$to $\mathrm{NO}_{3}{ }^{-} ; \mathrm{O}_{\mathrm{Nrec}}$ oxidation of recalcitrant organic $\mathrm{N}$ to $\mathrm{NO}_{3}{ }^{-}$(heterotrophic nitrification); $I_{N O 3}$, immobilization of $\mathrm{NO}_{3}{ }^{-}$to organic $\mathrm{N}$ pool; $D_{\mathrm{NO}}$, dissimilatory $\mathrm{NO}_{3}{ }^{-}$reduction to $\mathrm{NH}_{4}{ }^{+}(\mathrm{DNRA}) ; U_{\mathrm{NH} 4}$, plant $\mathrm{NH}_{4}{ }^{+}$uptake; $U_{\mathrm{NO}}$, plant $\mathrm{NO}_{3}{ }^{-}$uptake.
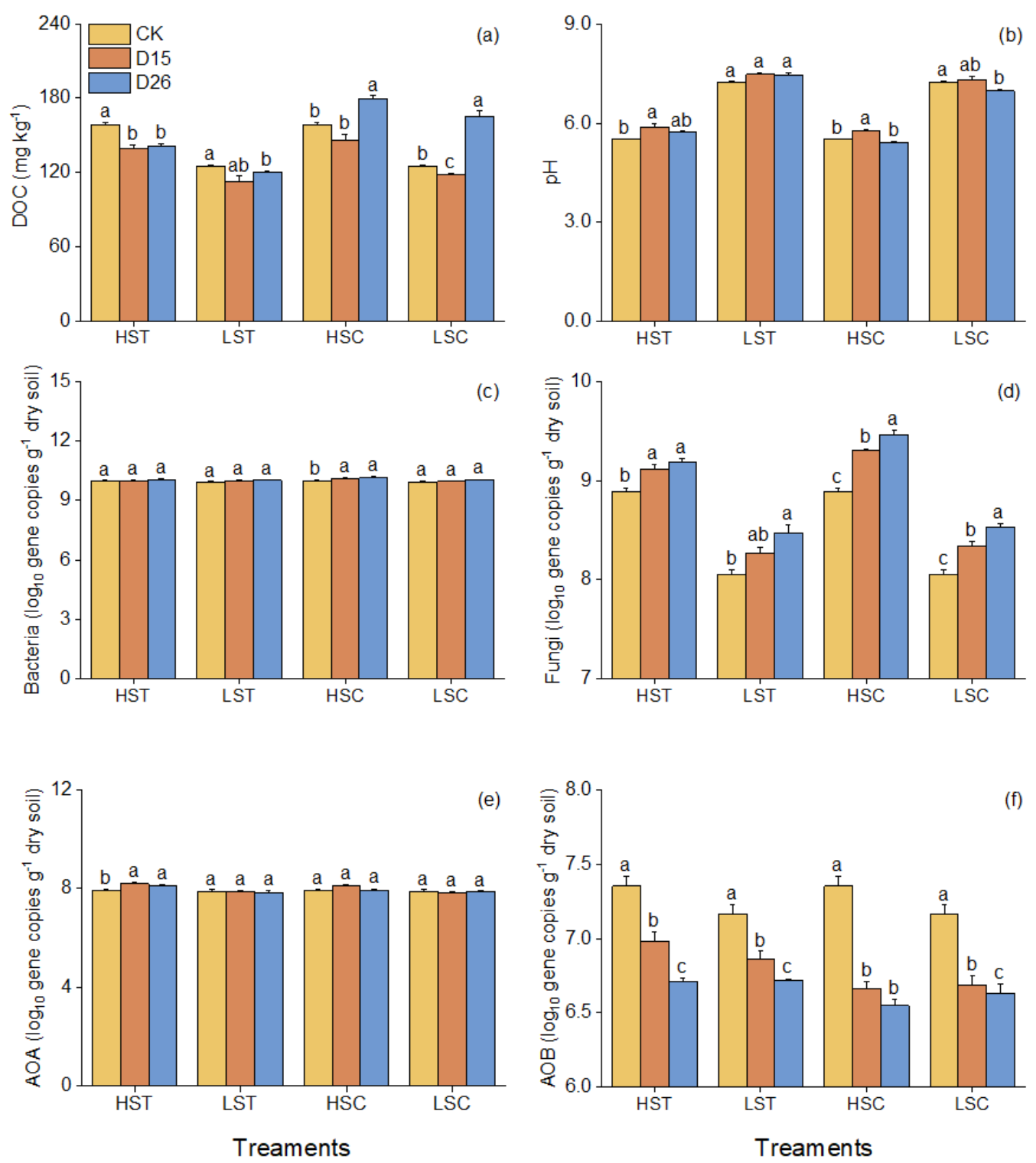

\section{Figure 2}

The dynamics of dissolved organic carbon (DOC) (a), $\mathrm{pH}(\mathrm{b})$ and abundances of bacteria (c), fungi (d), ammonia-oxidizing archaea $(\mathrm{AOA})(\mathrm{e})$ and ammonia-oxidizing bacteria (AOB) (f)

$\mathrm{CK}$, the control without planting; D15, planting for 15 days; D26, planting for 26 days; $\mathrm{HST}$, high $\mathrm{NO}_{3}{ }^{-}$-accumulation soil planting tomato; LST, low $\mathrm{NO}_{3}{ }^{-}$-accumulation soil planting tomato; $\mathrm{HSC}$, high $\mathrm{NO}_{3}{ }^{-}$-accumulation soil planting cucumber; $\mathrm{LSC}$, low $\mathrm{NO}_{3}{ }^{-}$-accumulation soil planting cucumber. Vertical bars represent standard deviations of the mean $(n=3)$. Different lowercase letters indicate significant differences among CK, D15 and D26 in each treatment $(p<0.05)$. 

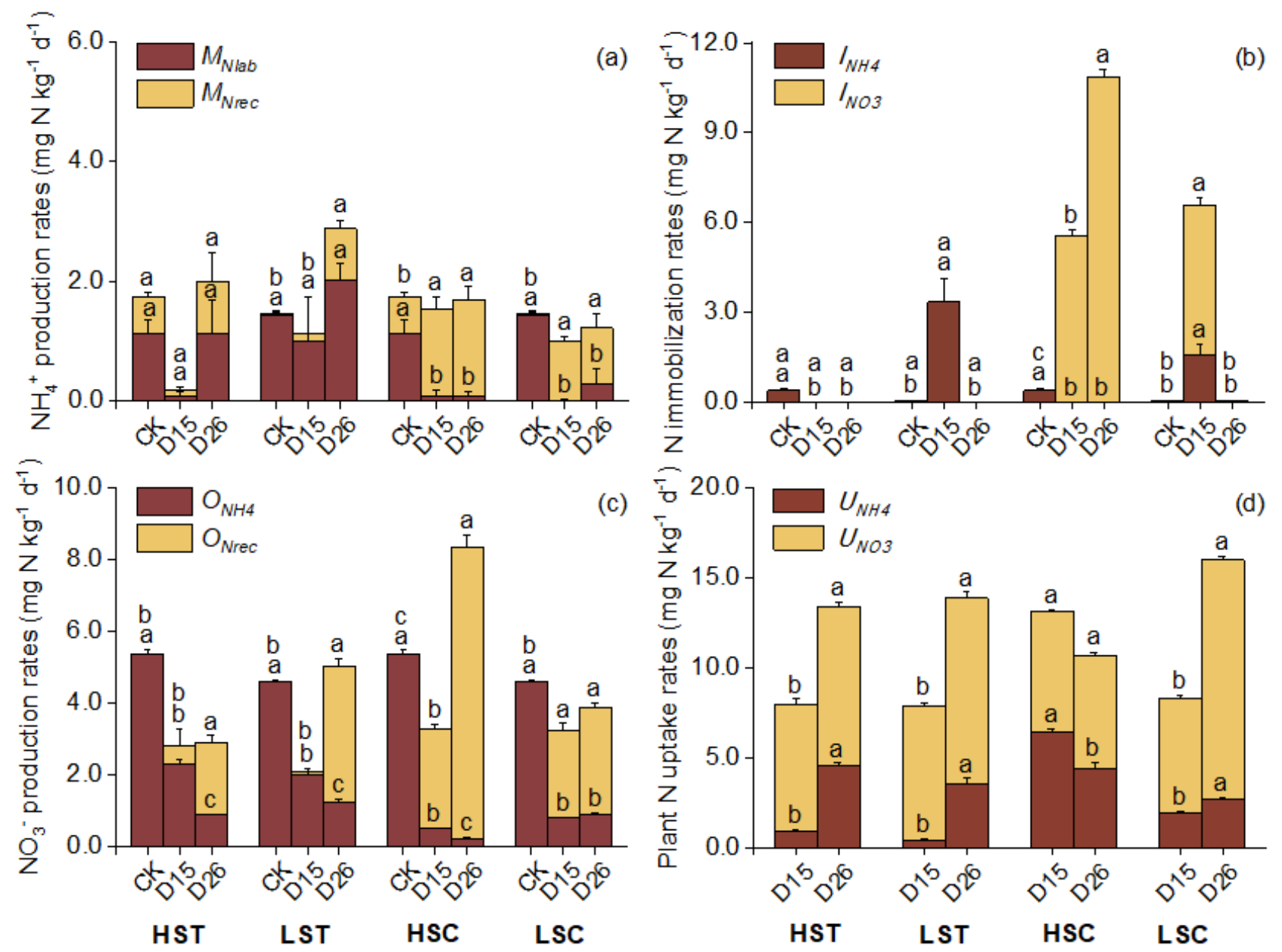

\section{Figure 3}

Gross $\mathrm{N}$ transformation rates in different treatments

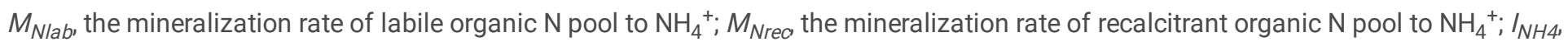
total gross $\mathrm{NH}_{4}{ }^{+}$immobilization rate; I IO3, immobilization rate of $\mathrm{NO}_{3}{ }^{-}$to organic $\mathrm{N}$ pool; $\mathrm{O}_{\mathrm{NH} 4}$ oxidation rate of $\mathrm{NH}_{4}{ }^{+}$to $\mathrm{NO}_{3}{ }^{-}$ (autotrophic nitrification); $\mathrm{O}_{\mathrm{NreO}}$ oxidation rate of recalcitrant organic $\mathrm{N}$ pool to $\mathrm{NO}_{3}{ }^{-}$(heterotrophic nitrification); $U_{\mathrm{NH} 4}$, plant $\mathrm{NH}_{4}{ }^{+}$uptake rate; $U_{N_{O} 3}$, plant $\mathrm{NO}_{3}{ }^{-}$uptake rate. $\mathrm{CK}$, the control without planting; D15, planting for 15 days; D26, planting for 26 days; $\mathrm{HST}$, high $\mathrm{NO}_{3}{ }^{-}$ accumulation soil planted tomato; LST, low $\mathrm{NO}_{3}{ }^{-}$accumulation soil planted tomato; $\mathrm{HSC}$, high $\mathrm{NO}_{3}{ }^{-}$accumulation soil planted cucumber; $\mathrm{LSC}$, low $\mathrm{NO}_{3}{ }^{-}$-accumulation soil planted cucumber. Vertical bars represent standard deviations of the mean $(n=3)$. Different lowercase letters indicate significant differences among CK, D15 and D26 in each treatment $(p<0.05)$. 

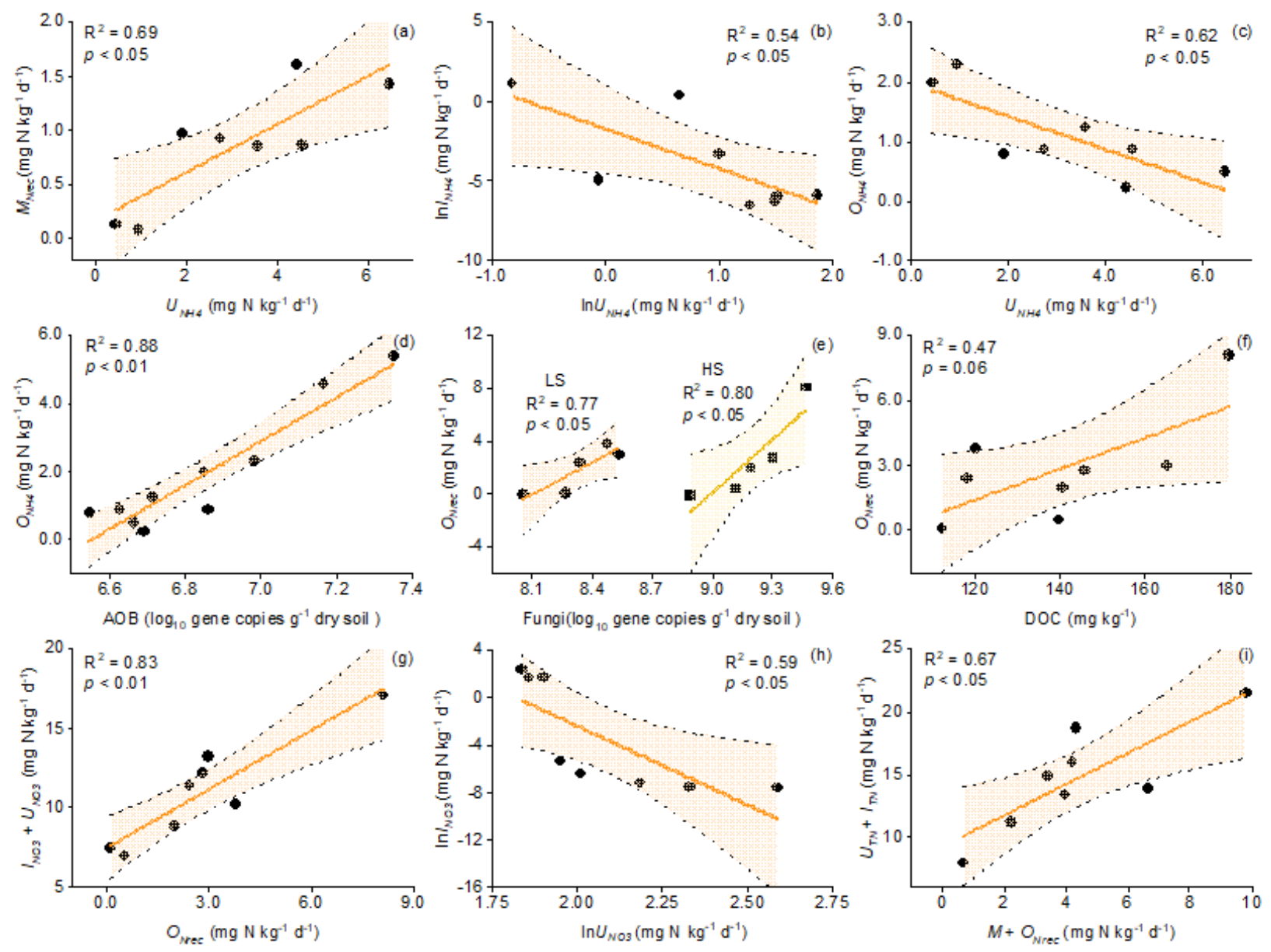

\section{Figure 4}

The relationships among gross rates of specific $\mathrm{N}$ transformations and measured soil properties

$U_{N H 4}$, plant $\mathrm{NH}_{4}{ }^{+}$uptake rate; $U_{N O 3}$, plant $\mathrm{NO}_{3}{ }^{-}$uptake rate; $U_{T N}$, the sum of $U_{N H 4}$ and $U_{N O 3} ; M_{N r e o}$ the mineralization rate of recalcitrant organic $\mathrm{N}$ pool to $\mathrm{NH}_{4}{ }^{+} ; \mathrm{O}_{\mathrm{NH} 4}$ oxidation rate of $\mathrm{NH}_{4}{ }^{+}$to $\mathrm{NO}_{3}{ }^{-}$(autotrophic nitrification); $\mathrm{O}_{\mathrm{Nreo}}$ oxidation rate of recalcitrant organic $\mathrm{N}$ pool to $\mathrm{NO}_{3}{ }^{-}$(heterotrophic nitrification); $I_{N H 4}$, total gross $\mathrm{NH}_{4}{ }^{+}$immobilization rate; $I_{N O 3}$, immobilization rate of $\mathrm{NO}_{3}{ }^{-}$to organic $\mathrm{N}_{\text {pool; }}$ $I_{T N}$, the sum of $I_{N H 4}$ and $I_{N O 3} ; A O B$, ammonia-oxidizing bacteria; DOC, soil dissolved organic carbon. The points represent average rate, and dashed lines represent the $95 \%$ confidence interval of the regression line.

\section{Supplementary Files}

This is a list of supplementary files associated with this preprint. Click to download.

- SupportingInformation.docx 